\title{
上腕骨近位端骨折の観血的治療例の検討
}

\author{
社会保険徳山中央病院整形外科 \\ 杉 谷大造・宮 本 龍 彦 \\ 住 浦 誠 治・二 武 皇 夫
}

\section{Investigation of Surgical Treatment of Proximal Humeral Fracture}

\author{
Daizo Sugitani, Tatsuhiko Miyamoto, Seji Sumiura, and Kimio Nibu \\ Department of Orthopaedic Surgery, Tokuyama Social Insurance Hospital, Yamaguchi Japan
}

\begin{abstract}
Among the patients with Humerus proximal fumeral fracture who were treated at our department during the past 5 years, 31 with fractures which were unstable or associated with marked dislocation were treated by surgery. Among the 31 patients, 9 underwent hemiarthroplasty, and 22 underwent open reduction fixation (hook plate percutaneous pinning and tension band wiring). The patients were all followed-up postoperatively. The results of treatment were assessed according to the JOA score in 29 cases. JOA scores assessed at thefinal visit were 79.9 in patients receiving hemiarthroplasty, 85 in those with hook plate, and 73.3 in those with tension band wiring. With respect to the adverse effects of treatment, 1 patient with tension band wiring had aseptic necrosis, 1 with hook plate had pseudoarthrosis, and 2 with hemiarthroplasty had a wire broken at the terminal-point of the major knot. The patients receiving hemiarthroplasty had relatively favorable outcomes when the terminal points of the major and minor knots were well handled and fixed (the mean JOA score was 88). Patients with hook treatment, even with 3-part or 4-part fractures, had relatively well fixed major knots, leading to favorable outcomes (the mean JOA core was 88.6).
\end{abstract}

Key words : Proximal Humeral fracture（上腕骨近位端骨折）, Surgikal treatment（観血的治療), Operativeindication (手術適応)

はじめに

上腕骨近位端骨折の多くは保存的治療により良好な 成績が得られている。しかし転位の大きな症例や整復 位保持が困難な症例に対しては手術的治療が選択され る. 今回手術的治療を行った上腕骨近位端骨折例につ いて検討したので報告する。

\section{対象と方法}

1995 年 4 月より過去 5 年間当科で手術を行った上 腕骨近位端骨折は 31 例, 男性 13 例, 女性 18 例, 手 術時年齢は 18 歳〜91 歳（平均 63.9 歳）であった。
受傷原因は転倒 16 例, 交通事故 10 例, 転落 5 例で あり, 転倒の 16 例中 15 例は 60 歳以上の高齢者であっ た。一方若年者は交通事故などの high energy の外 力による受傷が多かった。

骨折型は $\mathrm{Neer}^{3)}$ の分類で 2 part 骨折 9 例, 3 part 骨折 11 例, 3 part 脱臼骨折 1 例 4 part 骨折 7 例, 4 part 脱臼骨折 3 例であった.

手術術式は人工骨頭置換術を 9 例（3 part 骨折 4 例， 3 part 脱臼骨折 1 例， 4 part 2 例， 4 part 脱臼 骨折 2 例）に行い，観血的整復固定術（以下 ORIF） は22 例に行った。内訳は, フックプレートが 14 例 （2 part 5 例， 3 part 6 例， 4 part 3 例） 経皮的ピ二 
ング 5 例（2 part 3 例， 3 part 1 例， 4 part 1 例), tension band wiring 3 例 ( 2 part 1 例, 4 part 2 例), 31 例中追跡可能であった 29 例に対して術後成績を日 整会肩関節疾患治療成績判定基準（以下 JOA score） を用い評価した。術後追跡期間は 6 カ月〜 5 年，平均 1 年 10 カ月であった.

\section{結果}

最終診時の JOA score は, 人工骨頭が 79.9 , フッ クプレートが 85 , tension band wiring が 73.7, 経 皮的ピニングが 96.5 であった. 2 part 骨折において は後述する偽関節, 基礎疾患例（片麻㾇，精神分裂病） 以外はフックプレート 78.7, tension band wiring73, 経皮的ピニング 96 点であった． 3 part，4 part 骨折 中, 術後 1 ヶ月, 3 ヶ月, 6 ヶ月と最終診時の JOA score を術式別に示すと, (table 1) 人工骨頭置換術, フックプレート共に術後早期に比較的高い成績が得ら れた。 ピニングあ比較的良好で, 骨癒合とともに成績 の向上を認めた。

Tension band wiring は固定性不良で術後のリハ ビリが遅れ，成績不良であった。

全身合併症は特に認めなかった，局所合併症として 人工骨頭置換術においてワイヤーの折損が 2 例あり, 81 歳女性例は大結節が肩峰下に転位し, JOA score 37 点で特に不良成績であった。 2 part 骨折に対して 行ったフックプレート 1 例に偽関節を認めた. 術後 2 週目にベッドから転落し再転位を起こした。 術後 2 年 6 ケ月疼痛がないことから, 再手術は希望しなかった。 JOA score 65 点であった. Tnsion band wiring 中 1 例に aseptic necrosis を認めた。

Table 1

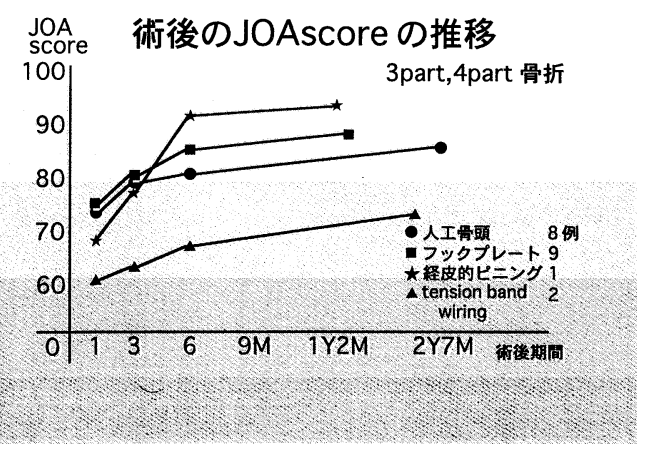

\section{症 例 供 覧}

（症例 1 ） 54 歳男性，乗船する際転落し受傷．近 医搬送され 3 part 脱臼骨折を認めた。整復試みるも 不成功なため受傷後 10 日目で紹介を受け，15 日目に 人工骨頭置換術を施行. 骨頭は脱臼し腋窩部より摘出し た. 術後 5 年時の ROM は前方挙上 $110^{\circ}$, 外転 $110^{\circ}$, JOA score 86 点と良好な成績を維持している. (図 1)

（症例 2) 44 際男性，消防用ホースがはずれ，こ れにて転倒. 4 part 骨折を認め, 受傷後 5 日目フッ クプレートにて骨接合術を施行. 受傷後 1 年 2 ヶ月目 に抜釘. 術後 2 年 10 力月の ROM は前方挙上 $160^{\circ}$, 外転 $150^{\circ}$, JOA score 98 点と良好な成績を得ている. (図 2)

（症例 3 ）自宅で転倒し 4 part 骨折を受傷.

Tension band wiring を行うも, 強固な固定性は 得られず， 3 力月後 wire のゆるみを認めた．７ヶ月 で抜釘をし 1 年 10 カ月の調查時, 骨頭壊死を認める が，JOA score 66 点で不良にもかかわらず利き手で ないため生活に不自由を訴えず，再手術の希望はない． (図 3)

\section{考察}

上腕骨近位端骨折の約 $80 \%{ }^{4)}$ は転位が小さく保存 的治療が選択される，転位のある骨折に対する治療法 として，2 part 骨折においては骨片の整復が不可能 かあるいは整復ができても骨片が不安定な場合には手 術的治療が用いられる。 3 part， 4 part 骨折に対し てはNeer は原則として 3 part 骨折に対しては観血的 整復之内固定を行うが一部は人工骨頭を適応とし，4 part 骨折は骨頭壊死の発生頻度が高いので人工骨頭 置換術としている.

当科に㧈いても人工骨頭置換術は川島 ${ }^{1)}$ らと同様に, 3 part 骨折のなかでも骨頭骨片が大結節骨片のなか に大きく転位しているすの，骨頭骨片に付着している 小結節部分が非常に小さく, 骨頭の血行障害が䯚念さ れる不安定型 3 part 骨折と 4 part 骨折を適応とした。 しかし 40 歳〜50 歳台あるいはそれ以下の不安定型 3 part，4 part 骨折に対しては ORIF を第一選択とし 人工骨頭置換術は 60 歳異常に行うことを一応の目安 としている.

人工骨頭置換術に於いては大結節，小結節の癒着が 適切に行われ，又維持された場合，さらに骨癒合を獲 

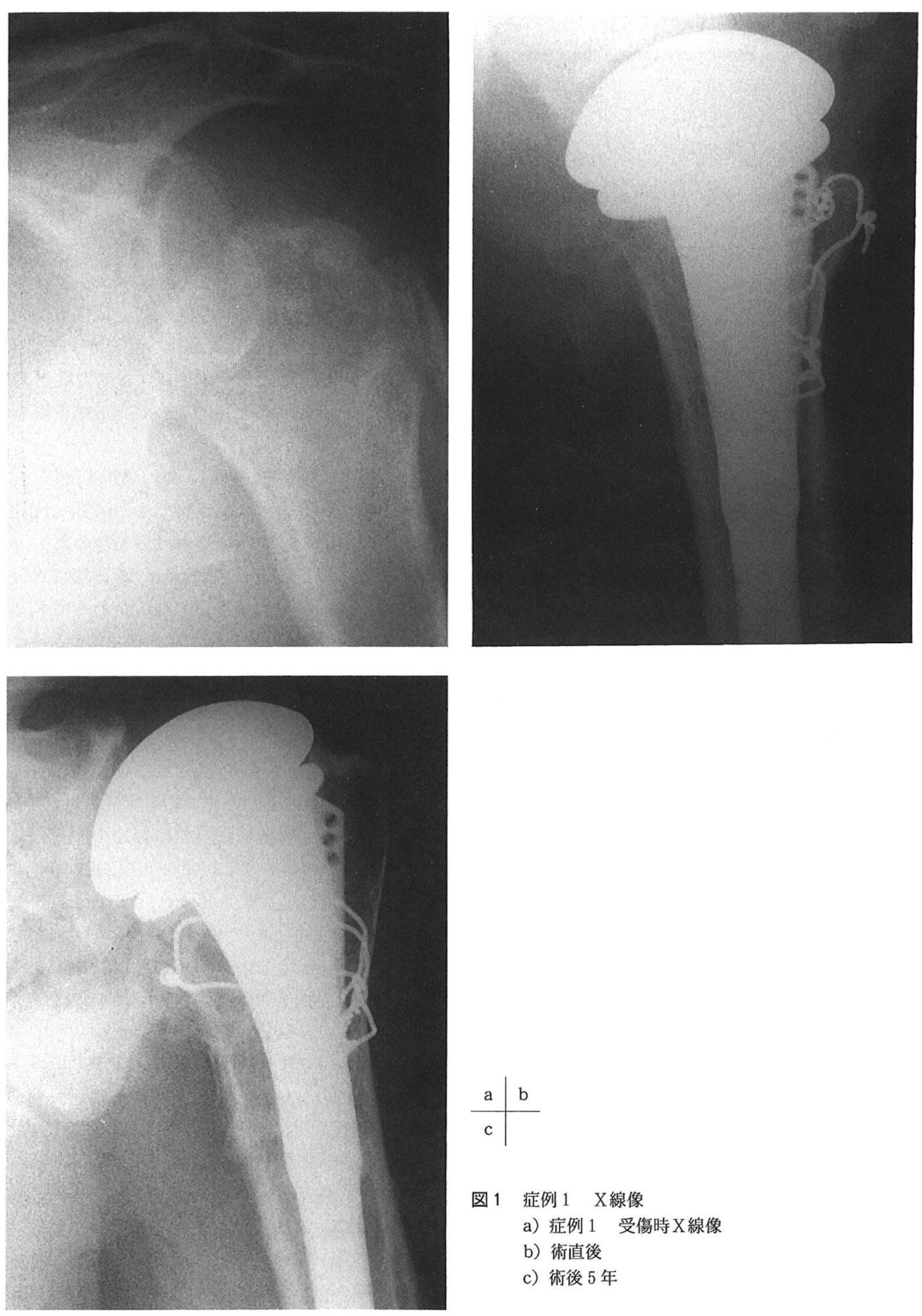

\begin{tabular}{l|l}
$\mathrm{a}$ & $\mathrm{b}$ \\
\hline $\mathrm{c}$ &
\end{tabular}

図1 症例 1 X線像
a) 症例 1 受傷時 $X$ 線像
b) 術直後
c) 術後 5 年 

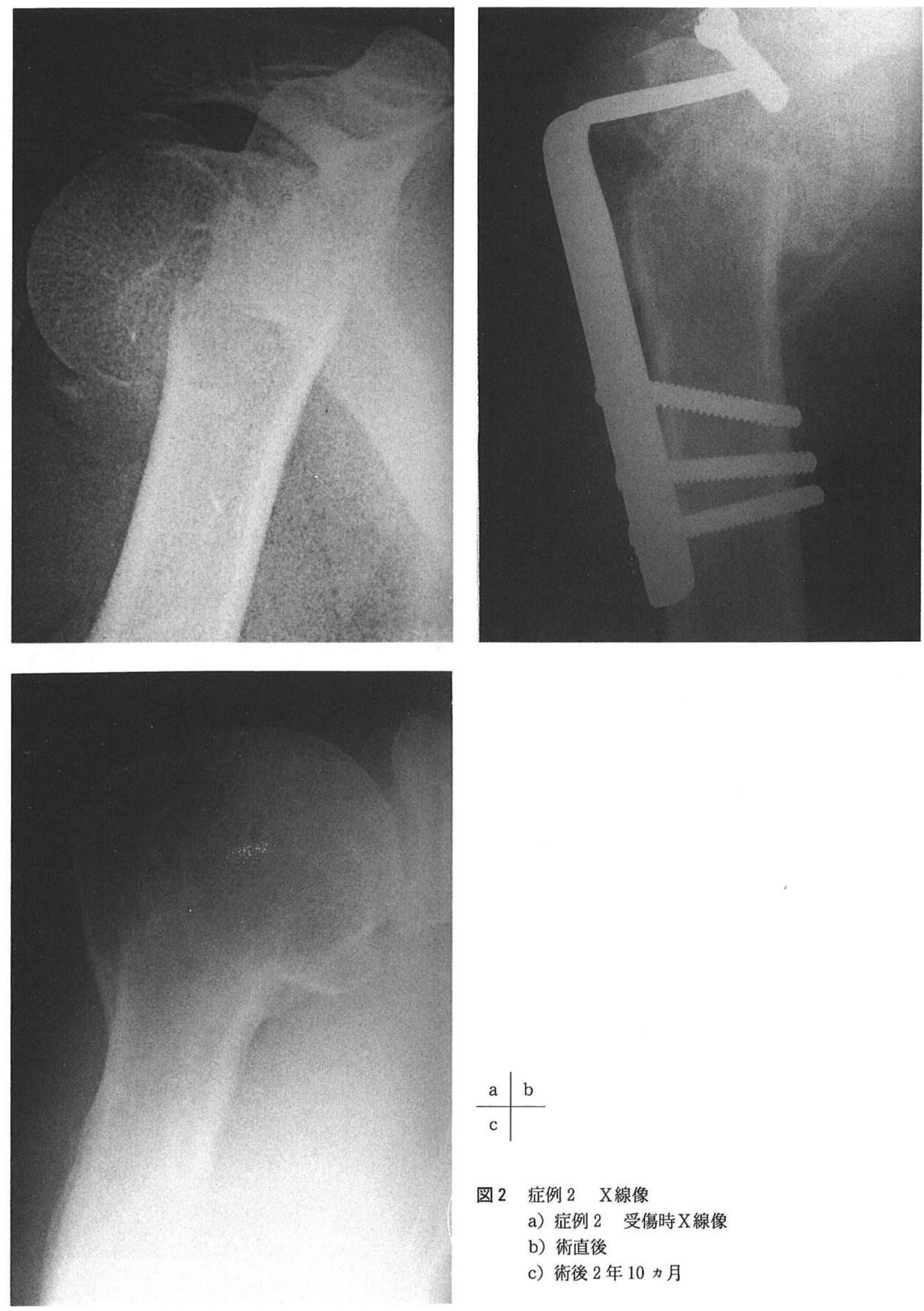

\begin{tabular}{l|l}
$\mathrm{a}$ & $\mathrm{b}$ \\
\hline $\mathrm{c}$ &
\end{tabular}

図 2 症例 2 X線像
a) 症例 2 受傷時 $X$ 線像
b) 術直後
c) 術後 2 年 10 力月 

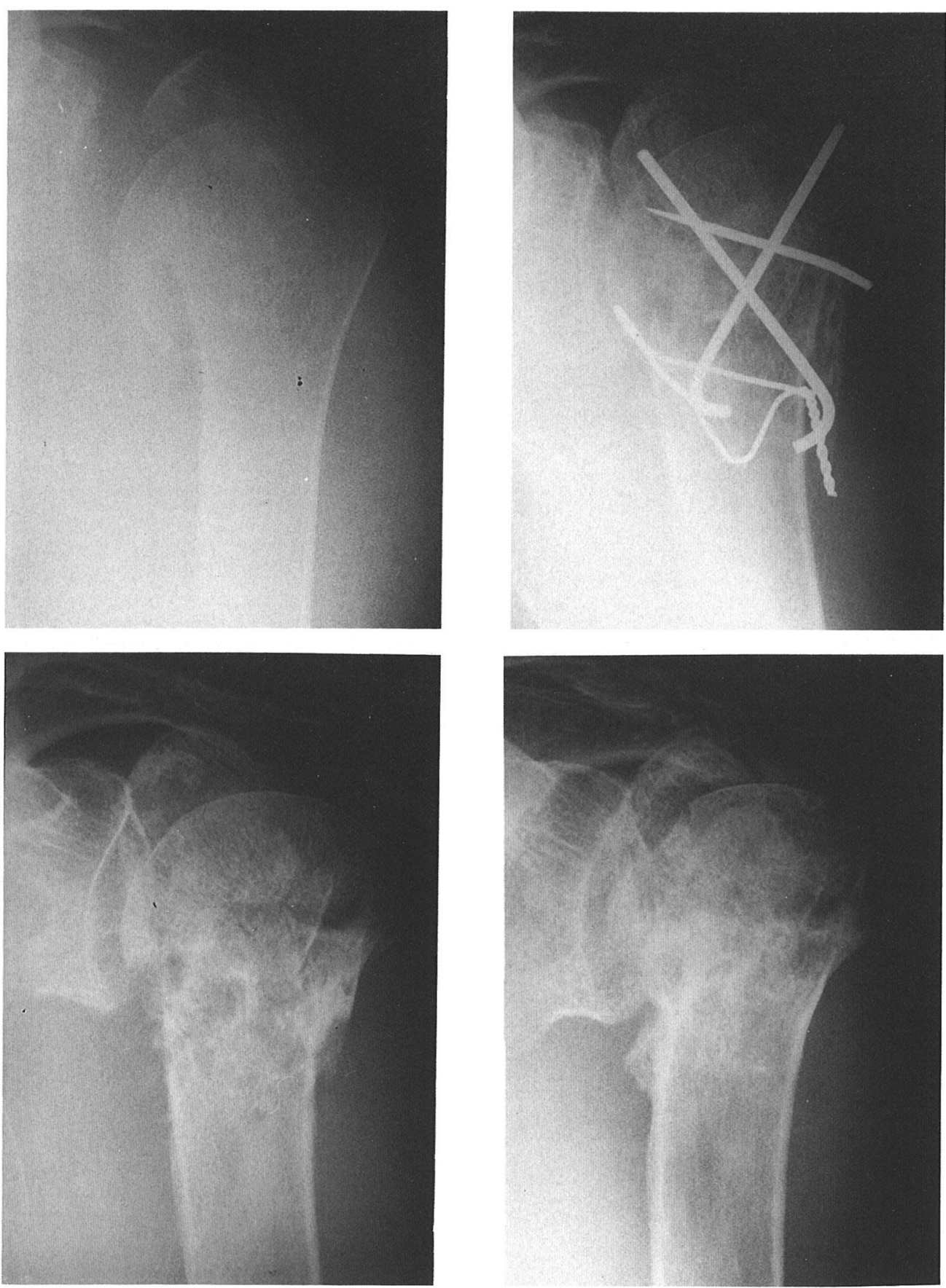

$$
\begin{array}{l|l}
\mathrm{a} & \mathrm{b} \\
\hline \mathrm{c} & \mathrm{d}
\end{array}
$$

図 3 症例 3 X線像

a) 受傷時 $X$ 線像

b) 術直後

c) 術後 7 ヶ月の抜釘後

d) 術後 2 年 10 力月

$$
-236-
$$


得できた場合は良好な結果を得ることができた5). （平均 JOA score 88 点)

ORIF については固定材料は多種多様で一定せず， これは骨折の手術の困難さを反映している，2 part 骨折においては限定した固定材はなく, 症例に応じ手 技的に慣れた方法を用いれば良いと考えている。しか し 3 part, 4 part 骨折は整復が困難で, 強固な固定 も得られ難い.これらに対してはプレート固定なかで あフックプレートを多用し，比較的良好な成績を得る ことができた.

フックプレートは森ら ${ }^{2)}$ が述べているようにフック 部がプレートと連続するため, 骨折部の回旋力や屈曲 力の強い抵抗を有している. 大結節が比較的固定しゃ すい為, 安心してリハビリが開始できる. 他のプレー トと比較して安価であるなどの特徵を有している.

フックプレートの適応は転位のある 2 part 骨折, 脱臼のない 3 part 骨折や若年者の 4 part 骨折などで あり，4 part 骨折に対しても比較的良好な結果が得 られた。 しかし OA 分類の C 型に含まれるものにつ いては骨頭部のフックの固定性が不十分である場合も あり，術中所見で固定が困難と考えられた場合につい
ては人工骨頭置換術も行える様, 配慮が必要である.

$$
\text { ま と め }
$$

（1）上腕骨近位端骨折 31 例に対し手術を施行し, 術 後成績をJOA score にて評価した.

（2）人工骨頭置換術は 60 歳以上の骨頭の血行障害が 㲘念される不安定骨折に対し有用であった.

（3） ORIF のうちフックプレートは 3 part, 4 part 骨折においても比較的良好な成績が得られた。

\section{参 考 文 献}

1) 川島 明：上腕骨近位端 3 分割骨折の観血的治療, Journal of Joint Surgery, Vol. 13. No. 6 : 701709, 1994.

2）森 英隆 : 上腕骨近位端骨折に対する hook plate の 生体力学的分析, 中部整災誌, $40: 1367-79,1997$.

3) Neer, C. S. II : Displaced Proximal Humeral Fractures. Part I. Classification and elevation. J. Bone joint Surg. 52-A : 1077-1089, 1970.

4）柴田陽三：Neer 分類と $\mathrm{AO}$ 分類の詳細と問題点, $\mathrm{MB}$ Ortop. 10(7): 11-18, 1997.

5）住浦誠治：上腕骨近位端骨折に対する人工骨頭置換術 の経験，骨折， 13 巻 : 46, 1991. 